CATALAN REVIEW

Catalan Review

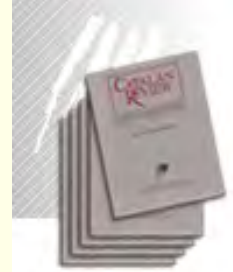

You are accessing the Digital Archive of the Catalan Review Journal.

By accessing and/or using this Digital Archive, you accept and agree to abide by the Terms and Conditions of Use available at http://www.nacs-

catalanstudies.org/catalan review.html

Catalan Review is the premier international scholarly journal devoted to all aspects of Catalan culture. By Catalan culture is understood all manifestations of intellectual and artistic life produced in the Catalan language or in the geographical areas where Catalan is spoken. Catalan Review has been in publication since 1986.
NORTH

AMERICAN

CATALAN

SOCIETY
Esteu accedint a l'Arxiu Digital del Catalan Review

A l' accedir i / o utilitzar aquest Arxiu Digital, vostè accepta i es compromet a complir els termes i condicions d'ús disponibles a http://www.nacs-

catalanstudies.org/catalan review.html

Catalan Review és la primera revista internacional dedicada a tots els aspectes de la cultura catalana. Per la cultura catalana s'entén totes les manifestacions de la vida intel lectual i artística produïda en llengua catalana o en les zones geogràfiques on es parla català. Catalan Review es publica des de 1986.

\title{
Trovas lemosinas or Llengua catalana: Majaderos de Castilla and the Many Names for the Catalan Language John S. Lucas
}

Catalan Review, Vol. XX, (2006), p. 301-311 


\title{
TROVAS LEMOSINAS OR LLENGUA CATALANA: MAJADEROS DE CASTILLA AND THE MANY NAMES FOR THE CATALAN LANGUAGE
}

\author{
JOHN SCOTT LUCAS
}

\section{ABSTRACT}

Previous attempts to understand the usage of the terms Catalan, Provençal, Occitan, and Limousin and the languages these designations represent have fallen short of any real analysis. Most scholars to date have either presented historical data without linguistic explication or have attempted to use the data to argue for particular political views on the question of Catalan and its many names. The present study of the names used for Catalan in different regions and at different times helps us understand the relationship of diglossia that existed between the Occitan and Catalan languages for about two hundred years and bears witness to the emergence of linguistic consciousness in Catalonia and in Valencia from the early Middle Ages to the Nineteenth Century.

$\mathrm{I}_{\mathrm{t}}$

$t$ is common knowledge among scholars of Catalan that the language came to be known as llemosi and that this designation is frequent in the literature of the nineteenth and early twentieth centuries. It is less evident, however, exactly how and when Limousin, a dialect of the Occitan language in southern France, came to be associated with Catalan, except that the troubadour poets are somehow to blame. The present study provides textual evidence from the thirteenth to the sixteenth centuries to illustrate the evolution of the term llemosi as a linguistic designation.

The term llemosi was coined in the thirteenth century and originally referred exclusively to Occitan. Catalan writers show a keen sense of linguistic awareness and consistently maintain this distinction until the nineteenth century, when llemosí is used to refer to the language in a self-conscious attempt to lend Catalan some of the literary prestige of the Occitan troubadours. ${ }^{\mathrm{T}}$ However, when Catalan writers of the Renaixença $a^{2}$ make this connection, they are aided by a tradition

I In "La Pàtria", Bonaventura Carles Aribau alludes to the troubadour tradition explicity in these verses, "Qué val que m'haja atret una enganyosa sort / a veure de més prop les torres de Castella, / si el cant dels trobadors no sent la mia orella, / ni desperta en mon pit un generós record?",

2 The word Renaixenç 'rebirth' is used to distinguish this nineteenth century reemergence of Catalan literary and linguistic consciousness from the Renaissance, which is called Renaixement in Catalonia. The movement, inspired in and drawing on 
that had already come into vogue in fifteenth and sixteenth century Valencia for entirely different reasons.

In Valencia, writers already began to call texts in Old Catalan llemosi to help distinguish the Catalan literary tradition from their own. Therefore, a study of the names used for Catalan in different regions and different times helps us understand the relationship of diglossia that existed between the Occitan and Catalan languages for about two hundred years and bears witness to the emergence of linguistic consciousness in Catalonia and in Valencia.

In an often-cited passage, Menéndez Pelayo ridicules the continued application of llemosi to the Catalan language up to the twentieth century:

¡Y que completa debía ser la ilusión cuando el trovador cantaba trovas lemosinas, como todavía llaman algunos majaderos de Castilla y de fuera de ella a los versos compuestos en lengua catalana!

Nevertheless, Menéndez Pelayo says little else that would be helpful in understanding how llemosi emerges in the literature as a name for the Catalan language.

A close look at the textual record reveals that, far from foolish, these majaderos from Castile were repeating a case of linguistic confusion that is revealing of the way the Catalan and Occitan languages developed during the medieval period.

By way of definition, the linguistic varieties known as Occitan roughly comprise a region that lies "between the Atlantic, the Pyrenees, and the Alps; its northern boundary, which is far more difficult to draw, passes somewhat south of the Loire River at a distance that varies from one region to the next" (Jensen 349). Most linguists now use the term Occitan to refer to the entire grouping rather than Provençal, which has the same disadvantage as Limousin, namely that it refers to just one geographical variety.

Contemporary linguists would characterize the relationship between Catalan and Occitan in Catalonia from about 1200 to 1400 as diglossia (Nadal and Prats I: 483). A term coined by Ferguson (1953), diglossia describes the situation that occurs when two or more languages are used in the same speech community but each is limited to specific registers or social functions. In this case, Occitan served as the language of high literature in the courts, particularly poetry, beginning sometime

Romanticism, is often dated from 1833 , with the publication of "La patria" by Bonaventura Carles Aribau, to 1892, with the first modernista literary celebration in Sitges. The various literary and cultural strands of this movement would continue to inform and influence modernism and the first vanguard movements until the foundation of the Second Republic in 1931 . 
in the early thirteenth century for Catalonia (a hundred years earlier in the Occitan-speaking regions). At this stage, Catalan did not have a literary voice of its own, and Occitan partially filled this void. Latin poetic forms, poesia, stood in contrast to the primarily oral and vernacular troves composed in Occitan.

Diglossia is an inherently unstable situation that tends to evolve either towards full bilingualism or the pre-eminence of one language over the other. ${ }^{3}$ This latter situation, known as language replacement, eventually occurs when Catalan acquires literary prestige and Occitan wanes in importance. Both Raimon Vidal de Besalú (fl. Irg6-1252) and Jofrè de Foixà (fl. 1250-1300) demonstrate an awareness of this situation already in the thirteenth century. Ausias March (1397-1459), the last Catalan troubadour, writes entirely in Catalan although heavily influenced by Occitan models. March, in contrast, says little about the language he uses; by this time the diglossic relationship has been almost completely resolved in favour of Catalan.

Early Occitan writers referred to their vernacular as romans or lenga romana to distinguish it from Latin (e.g. the fourteenth-century Leys d'amors by Guillem de Molinier). The first occurrence of llemosi to refer to the entire Occitan-speaking region comes not from Occitan writers themselves but from Catalans across the Pyrenees, who were also as likely to use the term romans as català or catalanesch to refer to their own vernacular. From the beginning, we observe an attempt on the part of Catalan writers to set up boundaries, to recognize that they spoke a different sort of romans from that of their troubadour cousins to the North.

Raimon Vidal de Besalú is the first Catalan to write about the relationship between the two languages; and his manual of Occitan grammar and stylistics, the Razós de trobar, contains the first use of the term llemosí in Catalonia. In his edition, Marshall dates the work between 1190 and 1213 based on linguistic evidence and references to historical figures in the text (lxix). Vidal is cited in later works such as the Regles de trobar of Jofrè de Foixà, which was dedicated to Jacme II, King of Sicily, who reigned from I286-1291. Terramagnino da Pisa, who resided in Sicily, recast Vidal's Razós into the rhymed Doctrina $d^{\prime}$ 'acort (c. 1282), closely following the original. Vidal is also mentioned

${ }_{3}$ Compare diglossia to a situation of bilingualism in which both languages are used with equal prestige in all social contexts. This is the case of Dutch and French in present day Belgium. With diglossia, however, generally one speech variety has greater prestige or authority, and speakers are tempted to switch languages in favor of the more prestigious variety. In this way, diglossia is often seen as inherently instable. The resurgence of bilingualism in twentieth-century Catalonia involves the implementation of language planning and educational strategies to foster the use of Catalan in all walks of life. To some degree, the present situation reflects an attempt to bring about reverse diglossia, that is to lend greater social prestige to the minority language. See Fishman for a full discussion. 
in the Leys d'Amors, which was promulgated by the Consistori de Gai Sabert in Toulouse around 1356 . Vidal's grammar, like his commentary on the languages used in the region, is innovative, and he paves the way for the use of the term llemosi by future writers in different contexts.

Vidal demonstrates a keen awareness of the distribution of the linguistic varieties and uses the words "nostra lingage," our language, much as we would use the word "language" or "language family" today, whereas "parladura" seems to refer to a specific geographic variety or speech community. Vidal explains precisely what he means by llemosi, explaining with striking accuracy the geographical boundaries of the Occitan-speaking region:

Totz hom qe vol trobar ni entendre deu primierament saber ge nenguna parladura non es naturals ni drecha del nostre lingage, mais acella de Franza et de Lemosi et de Proenza et d'Alvergna et de Caersin. Per qe ieu vos dic qe, qant ieu parlarai de "Lemosy", qe totas estas terras entendas et totas lor vezinas et totas cellas qe son entre ellas. Et tot l'ome qe en aqellas terras son nat ni norit an la parladura natural et drecha. (MS B, 8or $\left.{ }^{2}: 59-64\right) .^{5}$

Vidal also explains the proper functions of each language. His view that French is more suitable for concrete prose and llemosi for abstract poetic texts also reveals a surprisingly subtle awareness of the diglossic relationship among the different languages available.

La parladura francesca val mais et [es] plus avinenz a far romanz et pasturellas; mais cella de Lemosin val mais per far vers et cansons et serventes; et per totas las terras de nostre lengage so de maior autoritat li cantar de la lenga lemosina qe de neguna autra parladura, per q'ieu vos en parlarai primeramen (MS B, $\left.80 r^{3}: 72-76\right) \cdot 6$

Vidal probably chose llemosi rather than proensalés as the term for Occitan because of the prestige Limousin poets carried. The area around Limoges constitutes the cradle of prestigious troubadour poetry; and

4 The Consistori de Gai Saber was created specifically to revive the Provençal literary tradition in France and Catalonia. The entire tradition had all but died out in the wake of the Albigensian Crusades and subsequent incorporation of Occitania into the French Crown, which took place in the thirteenth century (Nadal and Prats I: 484-85).

5 "First of all, be aware that anyone who wants to know how to write troubadour poetry should understand that no speech is as natural and appropriate for poetry in our language as is the French variety from Limousin... and from all of those lands that surround it or neighbor it and all those lands in between. And all the men born and raised in these regions speak it naturally and properly" (Translation mine).

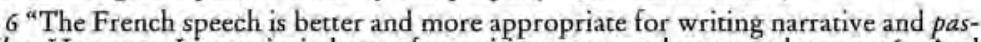
torelles. However, Limousin is better for writing verse and song and serventés. And throughout all the lands where our language is spoken, the songs in the Limousin speech variety have greater authority than any other form of speech, which is why I will speak of it first" (Translation mine). 
many of the most important poets came from that region, including Bernat Ventadorn ( $1477-1170)$, Giraut de Bornelh ( $162-1199$ ), and Arnaut Maruelh (fl, n95). Their compositions are among the first to arrive in Catalonia, the most influential, and the most widely diffused. The $\mathrm{Ca}-$ talan novel, Curial e Guelfa, is peppered with Occitan influence, and the razó or preface to the poem "Autressi con l'orifanz" by the Italian Berbezilh (fl, $1175-1215$ ) inspires, at least in part, the plot of this chivalric romance.

Like his predecessor Raimon Vidal, Jofrè Foixà also demonstrates a keen awareness of language and goes to some pains to differentiate Catalan from proensalés or llemosí. Foixà wrote his work while in residence at the court in Siciliy, where it was more common to use the term proensalés to refer to Occitan, no doubt because Provence was more closely connected to Italy geographically and culturally than Limoges. Foixà observes details such as phonological differences in the languages that can lead Catalan speakers astray:

Encara sapies qu'eu te do altra regal per raho d'alguns noms en los quals erron alcuns homs que usen de trobar, e assenyaladament en Cathalunya. E ells cuydon ho far per gallart parlar o per tal que mellors venga a llurs rimes, e fallen en així en los noms termenatz en -ars, en -ers, en -irs, en -ors, en -urs, que trason dels motz aquella letra $\mathrm{r}$, per que ls mudon d'enteniment e de lengatge... (MS H, 22 v b: 651-52).

In this passage, Vidal refers to the suppression of $/ r /$ in certain phonological environments such that /amórs/ is pronounced [amós]. Foixà also cautions writers not to introduce foreign French or Catalan vocabulary items into their Occitan texts except, of course, where the word happens to exist in both languages. Of these words, Foixà notes:

...E dels damunt ditz motz potz pendre eximpli per aquestz: pais, va, sus, e d'altres motz qui son frances e lemosi; així com dona o castell, saber, haver, e motz d'altres qui son Catalans e proençals; mes en los cantars son mes proençals que altres $^{\mathrm{g}}$ (MS H, $15^{\mathrm{r}} \mathrm{a}, 183-84$ ).

Although Catalan trobadours enjoyed great prestige, there is tradition in Occitan literature of correcting them for grammatical and

7 "Now, I will give you another example regarding mistakes that some troubadours make regarding certain nouns, specifically in Catalonia. And they tend to do this in order to sound more bold or so that their rhymes will come off better. And thus they make mistakes this with nouns ending in -ars,-ers,-irs,-ors, and-urs, in that they take the letter " $\mathrm{r}$ " out of these words, thereby altering understanding and language" (translation mine).

8 And as an example of these words, you have: pais, va, sus, and other words that are French and Limousin; as well as dona o castell, saber, baver, which are Catalan and Provençal; but when used in song they are more Provençal than anything else" (translation mine). 
other mistakes. The Occitan poet Molinier, who developed the ground rules for the Jocs Florals, the literary contests of the fourteenth century, follows Vidal's tradition. He criticizes the Catalans, however, for their confusion of open and close vowels, which evolve differently in Occitan:

Li Català so gran dictayre,

Pero d'aysso no sabon gayre,

Car de petit fan plenier so (436-38).

This incipient linguistic consciousness in Catalonia appears quite early and the complex diglossic relationship between Catalan and Occitan continued for two hundred years, well beyond the waning of the troubadour tradition in the Occitan region. After the defeat of combined Catalan and Occitan armies during the battle of Muret in I213 and the Peace of Paris in 1229, most of the Southern counties in France, specifically the area around Toulouse, are brought under direct influence of the French crown for the first time. It is beyond our scope to consider the tremendous influence this geopolitical situation, especially the institution of the Inquisition in France, would have on those lands. Suffice it to say that without prosperous and independent courts, the troubadour literary tradition could only be kept alive or at least on life support in Catalonia.

The Provençal writers often referred specifically to the conflict in their works, encouraging their countrymen to fight against the French invasion. This sirventés by Bonifaci de Castellana exemplifies their efforts:

Sitot no m'es fort gaya la sazos, un sirventes faray ab digz cozens, en cuy diray, contra tots recrezens, als provensals paubres e cossiros que non lur laysson braya esti frances, a l'avol gen savaya; ans les tenon tant en menhs de non-re, eges per tant non lur clamon merce?

All of this was in vain, of course. The ink on Castellana's song was barely dry when his eponymous city fell and he had to seek refuge in the court of Pedro de Aragon across the border.

9 "Although it be for an unhappy occasion, I will write a sirventés with sharp words for all the cowards. And I will say to the poor provencalese that these French and their evil henchmen have left them with without so much as their underware. They think of them as less than nothing, and so they should never beg them for mercy" (translation mine". 
In 1323, a group of litterati in Toulouse managed to stage a revival of Occitan poetry, in part what we would today call a nationalistic reaction to the unification of the Occitan regions under the French crown. This institution, known as the Jocs Florals, would last until 1484 in France (Nadal and Prats 1: 484-5). By I338, Pere el Ceremoniós personally oversees similar competitions in Lleida during which a group of experts gave their opinion on a series of poems, literally songs: "super arte dictandi et faciendi pulcra carmina sive" (Nadal and Prats r: 485). The archives preserve as well an edict from Joan I in 1393 in which he orders a festival of Gaya sciència be instituted every year on either the feast of the Mother of God or on Pentecost Sunday.

Apparently the annual celebration took place in 1394 and 1395 for, in another letter, the King specifically requests that the tradition continue. Joan extols the virtues of the gaya sciència as a way to instruct the young and keep idle minds and idle hands from going astray: "no stiguen ociosos, los quals en res no poden ésser tan inclinats a lunyar-se de ociositat, com ab conseguir coses profitoses e plasents". He insists that the festivities continue, that lavish prizes be awarded, "semblants joyes que l'any passat foren donades als trobadors", and he ensures the city that these events will bring great honor to Barcelona, "ornarà en gran honor d'aqueixa ciutat" (Rubió I Lluch r:384).

The Consell de Cent, the Barcelona town council, does not exactly see eye to eye with the king on this point (Rubió i Lluch r: 384 ). Preoccupied by the sorry state of local finances, and other expensive requests by the King, ${ }^{\text {to }}$ the city council basically tells the king that troubadour poetry really is not that much of a priority, certainly not of any practical value, and if he feels otherwise, he can come up with the cash himself.

Del fet de la Gaya Sciència, deliberà lo dit Consell que, per los grans e importables càrrechs que la ciutat ha, e per lo poch millorament que aconsegueix de la dita Gaya Ciència, que les dites joyes no sien donades per la Ciutat, mas qui posar-n'i volrà, que n'i pos. (Rubió i Lluch: 1: 384).

Joan's successor, Martí l'Humà, takes personal responsibility for the celebrations, bringing them directly under Royal patronage in 1398 . This attempt by the court to maintain some sort of troubadour tradition and carve out a permanent place for the Occitan literary tradition is short lived. Descriptions of the last celebrations are preserved by Enrique de Villena in the Arte de trobar.

By the sixteenth century, Valencian authors consistently call texts written in Catalan from the twelfth to the fourteen centuries llemosi in

Io For example, the city had to play host to Pope Benedict XIII and his entire court among other concerns (Rubió i Lluch i: 384). 
contrast to their own speech, which they call more frequently valencià. It is tempting to draw a parallel between modern-day Hispanics who prefer to call their language castellano to avoid being associated with Spain. It would, however, be anachronistic to call this evidence of incipient linguistic nationalism in Valencia, as so many misguided politicians want to do today.

Rather than nationalism, what began to occur in sixteenth-century Valencia is something similar to the linguistic situation in Catalonia from the twelfth to the fourteenth centuries. By the fifteenth century, a tradition of diglossia emerged in Valencia in which Castilian became the language of non-fiction prose, whereas Catalan was restricted to religious works, poetry, and little else (Fuster 22). Catalan, or as it was known to them, valenciano, was primarily an oral means of expression. The last work of prose fiction to be published in valenciano was Tirant lo Blanc in $\mathrm{I} 490$. Many fifteenth-century publishers self-consciously chose to translate or publish original texts in Castilian to make a better profit.

The first indication that Valencians no longer identify entirely with the speech of the Principat ${ }^{11}$ comes from the preface, the epistola prohemial, that Joan Bonllavi attached to an edition of Llull's Blanquerna, which he published in r52r. In this edition, Bonllavi claims to have translated the archaic text from the "llengua llemosina primera" into "aquesta llengua valenciana bastarda" (Fuster ig). Bonllavi, a fervent Llull enthusiast, essentially modernized the text to give it wider appeal, but there is no hint that the two linguistic varieties are really different languages. Bonllavi equates Ilemosi with Old Catalan. Fuster hypothesizes that Bonllavi may have been working from an older manuscript with some Provençal influence (19). By this time, the language of Ramon Llull would likely have appeared archaic to Bonllavi and his contemporaries.

Juan Justiniano, in his 1529 Castilian translation of Joan Lluís Vives' De institutione feminae christianae, claims that the language of Francesc Eiximenis was "llemosi", a somewhat more disturbing claim.

Fray Francisco Ximenz...el qual con paternal caridad emprendió de hecho el cargo de instruir y doctrinar las mugeres cristianas: y así cogiendo muchas autoridades y ejemplos, tanto de Gentiles como de Cristianos, hizo un gran libro intitulado: libro de las donas; en el qual, aunque enseñó muchas cosas útiles y dignas de saberse de todos; pero escribiólas en la lengua de la qual gozasen pocos; porque escribió en Lemosí, que es una lengua por sí entre Cataluña

In The Principat is the name traditionally given to the original Catalan counties brought together under the rulc of the Catalan Count-Kings. It is often used to distinguish the present-day Autonomous Community of Catalonia from other Catalan-speaking regions, such as Valencia and Andorra. 
y Gascón, que entonces se usaba por estos Reynos de Valencia y Cataluña; contentándose de alumbrar solamente y dar razón a sus ovejas, como buen Pastor, sin alargarse a más (in Fuster 19).

Both of these authors show some reverence for the archaic language they call llemosi. They also indicate an understanding of linguistic unity. Justiniano expressly states that llemosi was spoken in the Kingdoms of Catalonia and Valencia. Far from a linguistic nationalist, Justinano is a pragmatist seeking to make his works appeal to a wide Justiniano. Llemosi is a convenient label to distinguish literary Catalan from the local variety.

If Justiniano alludes to the diglossic relationship between Catalan and Castilian, Pere Antoni Beuter makes this distinction explicit. Beuter originally wrote a chronicle of Valencia in Catalan. He rewrote the text in Castilian in 1546 with financial support from the city council and justifies his linguistic choice this way:

Pues como el tiempo ha traydo la diuersidad de tantos reynos como en España se partieron (por la venida de los Moros) en vn general y solo Señorío, excepto el reyno de Portugal, paresce que el mesmo tiempo requiere que sea en todos vna comun lengua, como solia en la Monarchia primera de España en tiempo de Godos. Luego no es razón que a nadi parezca mal, que siendo yo Valenciano natural, y escriuiendo de Valencia [...] escriua en Castellano, lengua estraña para Valencia, por el respecto del provecho común, y divulgación y amor en toda España. (Beuter in Fuster 22-3).

Nevertheless, Beuter, unlike his contemporaries, shows some degree of contempt for the old language:

Que cosa muy aueriguada es que al ingenio aprouecha lo que del ingenio sale. Y por el mesmo respecto lo que mucho al ingenio despierta, de gran ingenio procedió. Que tal sea nuestra lengua Valencia, de las trobas y obras de los antiguos Valencianos, avn en tiempo que no estaua la lengua tan limada, que por esso nosotros le dezimos el antiguo Limosin, se paresce... (Beuter in Fuster 23).

That Catalan should be called limo-sin, literally "without polish", will become a literary commonplace in later centuries. Beuter is but one witness to the diglossic relationship that existed between Castilian and Catalan in the region.

From the sixteenth century onward, the confusion between llemosi and catala will become greater, with false etymologies of all sorts popping up to justify the term. Alongside the limo-sin, without polish, etymology, we have the myth that Jaume I, originally from Montpellier, learned llemosi from his mother and brought that dialect to the Valencian region during the period of repopulation. In either case, the purpose is to label literary Catalan archaic and of little use 
when addressing a wider audience. The erosion of the diglossic relationship between Catalan and Castilian in Valencia is evident in the sixteenth century, and it continues down to the present day.

This brief exposition of the data demonstrates that two different cases of diglossia have taken place. We have seen how Catalan and Occitan stood in a relationship of diglossia by examining how the two languages, catala and llemosi, were kept distinct in the minds of the thirteenth-and fourteenth-century writers. The use of the term llemosi in Catalonia was, from the outset, carefully chosen and defined. The two languages were understood to be distinct until llemosi simply faded away into the Occitan-peppered prose of Ausias March in the fourteenth and fifteenth centuries. At this point, language replacement has occurred in Catalonia, at least, where Occitan ceases to be used in any context or felt to be a local language.

The second case of diglossia is more complex. The early Valencian writers seemed to have some vague consciousness of their connection to Catalan, but the distinction begins to fade by the fifteenth and early sixteenth centuries. First Old Catalan became the unpolished llemosí, while the contemporary vernacular was still called català or valencià indistinctly. Finally, Beuter and his contemporaries conflated the two languages completely. From then on, the catala and llemosi are somehow permanently united in the collective linguistic consciousness in both regions. In Valencia, Catalan/Valencian stands in a diglossic relationship to Castilian, which was very clearly identified as the appropriate language of literary and cultural production, whereas Catalan/Valencian was primarily a spoken dialect, relegated to the home in general and, specifically, to the rural hinterland. In Valencia, the process of the linguistic replacement of Catalan/Valencian with Castilian continues to the present day.

JOHN SCOTT LUCAS IES CHICAGO

\section{WORKS CITED}

\section{Primary Sources}

ARIBAU, Bonaventura Carles. "La patria”. El vapor, 24 Aug. 1833. Bonifaci de CASTtellañ. "Sitot no m'es fort gaya", in Martín de Riquer and Isabel de Riquer, eds. La poesía de los trovadores. Madrid: Espasa, 2002. 
Guillem de Moliner. Leys d'amors. Ed. Joseph Anglade. 4 vols.

New York: Johnson Reprint, 1971. [Paris: Picard, 1915-1920].

JOFRE DE FoIXA, Regles de trovar. in J. H. Marshall, ed. The Razos de trobar of Raimon Vidal and Associated Texts. London: Oxford UP, 1972.

RuBIó I LluCH, Antoni. Documents per l'història de la cultura catalana migeval. 2 vols. Barcelona: Institut d'Estudis Catalans, I908I92I.

Torremagnino de PisA. Doctrina d'Acort. in J. H. Marshall, ed. The Razos de trobar of Raimon Vidal and Associated Texts. London: Oxford UP, 1972 .

Vidal, Raimon. Razos de trobar. Ed. J. H. Marshall. The Razos de trobar of Raimon Vidal and Associated Texts. London: Oxford UP, 1972.

\section{Secondary Sources}

Ferguson, Charles. "Diglossia." Word Is (1959): 325-40.

FisHMAN, Joshua, 1967. "Bilingualism With and Without Diglossia; Diglossia With and Without Bilingualism." Journal of Social Issues 23 (1967): 29-38.

FUSTER, Joan. "Notes sobre el 'llemosi' a la València del segle XVI." In Homenatge a Joan Fuster. Eds. Vicent Andrés Estellés et al. Girona: Estudi General, 1984.

JENSEN, Frede. "Language." In F. R. P. Akehurst and Judith M. Davis, eds. A Handbook of the Troubadours. Berkeley: U of California $\mathrm{P}, 1995$.

MENÉNDEZ Y PIDAL, Marcelino, prologue to Lo gayter del llobregat, poesias de D. Joaquín Rubió i Ors, vol. 2. Barcelona: Edición Poliglota, 1888-1889.

NADAL, Josep and Modest PrATS. Història de la llengua catalana, $5^{\text {th }}$ ed. 2 vols. Barcelona: Edicions 62, 1996. 